\title{
Pengaruh Perubahan Pelayanan Kesehatan Rumah Sakit Umum DAERAH DR. MOEWARdi TERHADAP PEMANFAatan LaHAN KOMERSial Di SEKitARNYA di SURAKarta
}

\author{
Nofa Yuniary, Murtanti Jani Rahayu, dan Rufia Andisetyana Putri \\ Program Studi Perencanaan Wilayah dan Kota \\ Fakultas Teknik \\ Universitas Sebelas Maret, Surakarta \\ email: nofayuniary@yahoo.com
}

\begin{abstract}
Rumah Sakit Umum Daerah Dr. Moewardi is a national scale-hospital provided by Central Java provincial government in the city of Surakarta. Assigned as a class hospital in 2007, Rumah Sakit Umum Daerah Dr. Moewardi led the citizen to have health service. The main activity of the district will be followed by the other development of the second activity. Hospital is one kind of main activities that can give impact to surrounding environment. Commercial activity area which is grow up around the hospital, such as boarding house, food court, convenience store and the other commercial services, gives impact to the sector's revolution around the hospital. The issues in the research is the other utilization of the commercial area around the hospital which is effected by the change of health service of Rumah Sakit Umum Daerah Dr. Moewardi. This research aimed to find out the effect of Rumah Sakit Umum Daerah Dr. Moewardi's health service change to the utilization commercial area around the hospital. The method used is deductiveexplanative descriptive analysis technique. The data collected is a real observation, respondent interview and document-based data. The result of the research shows that the service of Rumah Sakit Umum Daerah Dr. Moewardi is increasingly change by the years. It equals with the utilization of the commercial area around Rumah Sakit Umum Daerah Dr. Moewardi which is also increasing the commercial area so it can be concluded that the health service in Rumah Sakit Umum Daerah Dr. Moewardi gives impact to the utilization of commercial area around because both changes that increased.
\end{abstract}

Keywords: development of health services, commercial land use change

\section{PENDAhUluan}

Kota Surakarta berperan sebagai penggerak utama bagi kabupaten sekitarnya karena menjadi pusat kegiatan dan pelayanan publik yang lebih maju dibandingkan dengan kabupaten lain. Salah satu bentuk pelayanan publik berskala nasional tersebut adalah Rumah Sakit Umum Daerah Dr. Moewardi yang disediakan oleh pemerintah Provinsi Jawa Tengah.

Pada tahun 2007, Rumah Sakit Umum Daerah Dr. Moewardi mendapatkan predikat sebagai rumah sakit umum kelas A yang mempengaruhi masyarakat untuk datang ke rumah sakit dalam mendapatkan pelayanan pengobatan. Masyarakat yang datang untuk berobat tidak hanya berasal dari Kota Surakarta saja, namun dari luar Kota Surakarta, seperti Kabupaten Klaten, Kabupaten Boyolali, Kabupaten Wonogiri, hingga Kabupaten Pacitan. Selain itu, rumah sakit ini menjadi pusat pendidikan bagi mahasiswa Fakultas Kedokteran Universitas Sebelas Maret dan universitas lainnya untuk melakukan kerja praktik dan proses akademik lainnya sehingga berimplikasi kepada berubahnya pemanfataan lahan dengan fungsi komersial yang semakin menjamur di sekitar kawasan Rumah Sakit Umum Daerah Dr. Moewardi dari tahun ke tahun. Kegiatan utama pada suatu kawasan akan pula diikuti oleh berkembangnya kegiatan lain sebagai kegiatan pendukung di sekitar kegiatan utama. Rumah sakit adalah salah satu jenis kegiatan utama yang dapat memberikan dampak terhadap kawasan sekitarnya. Kegiatan pelayanan kesehatan yang berlangsung di Rumah Sakit Umum Daerah Dr. Moewardi mempengaruhi tumbuh dan berkembangnya kegiatan pendukung di sekitar kawasan rumah sakit, seperti tuntutan akan kebutuhan hunian sehingga memunculkan lahan dengan kegiatan indekos dan kebutuhan harian yang juga memunculkan banyaknya warung makan di sekitar Rumah Sakit Umum Daerah Dr. Moewardi.

Penelitian ini dimaksudkan untuk mengetahui pengaruh dari perubahan pelayanan kesehatan yang ada di Rumah Sakit Umum Daerah Dr. Moewadi terhadap perubahan pemanfaatan lahan komersial di 
sekitarnya dengan ruang lingkup waktu penelitian pada tahun 2007 dan tahun 2016.

\section{TINJAUAN PUSTAKA}

Pemanfaatan lahan sebagai sejumlah pengaturan, kegiatan, dan masukan yang dilakukan oleh manusia pada tanah tertentu yang pemahamannya lebih rinci jika dibandingkan dengan penggunaan lahan (Sardi dalam Wicaksono, 2011).

Menurut Chapin (1985), perubahan lahan merupakan interaksi yang disebabkan oleh tiga komponen pembentuknya, yaitu sistem pengembangan lahan adalah pengembangan dengan pembangunan sarana sebagai penyesuaian bagi kegunaan manusia dalam mendukung sistem kegiatan yang ada sebelumnya, sistem kegiatan adalah wadah bagi kegiatan manusia yang akan membentuk suatu pemanfaatan lahan tertentu, dan sistem lingkungan hidup adalah berkembangnya fungsi lahan dengan unsur-unsur biotik dan abiotik yang dihasilkan oleh alam.

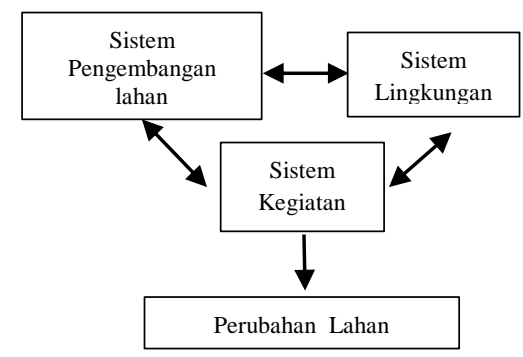

(Chapin, 1985)

Kegiatan pendukung yang berada dalam kawasan komersial adalah semua fungsi bangunan dan kegiatan-kegiatan yang mendukung ruang-ruang publik suatu kawasan kota.

Keberadaan pusat kegiatan utama pada suatu kawasan akan mengakibatkan muncul dan berkembangnya kegiatan-kegiatan pendukung (Lynch dalam Marhendriyanto, 2003). Kondisi tersebut mempengaruhi terjadinya perubahan pemanfaatan lahan, khususnya lahan dengan kegiatan komersial.

Pelayanan kesehatan merupakan pelayanan dalam memenuhi kebutuhan masyarakat berupa tindakan penyembuhan, pencegahan, pengobatan, dan pemulihan fungsi organ tubuh seperti sedia kala. Pelayanan kesehatan terdiri dari pelayanan rawat inap, pelayanan rawat jalan, pelayanan gawat darurat yang disediakan oleh rumah sakit. Kegiatan pelayanan kesehatan yang dilakukan oleh sebuah rumah sakit tidak terlepas dari keberadaan pemangku kepentingan yang akan memberikan dampak terhadap perubahan lahan. Adanya pemangku kepentingan akan memunculkan pemusatan kegiatan komersial di sekitar kawasan (Weber dalam Tarigan 2005). Adanya peningkatan kebutuhan pelayanan juga akan mempengaruhi tingkatan kepadatan penduduk yang akan menyebabkan intensitas bangunan pun menjadi meningkat (Wicaksono, 2011). Hal ini yang kemudian akan mempengaruhi perubahan pemanfaatan lahan komersial di sekitar Rumah Sakit Umum Daerah Dr. Moewardi.

\section{METODE PENELITIAN}

Metode penelitian ini berisi ruang lingkup penelitian dan metode analisis yang digunakan untuk mengetahui pengaruh perubahan pelayanan kesehatan Rumah Sakit Umum Daerah Dr. Moewardi terhadap perubahan pemanfaatan lahan komersial di sekitarnya

\subsection{Ruang Lingkup}

Batasan area pada penelitian ini didasarkan pada radius sejauh 400 meter dari pintu Rumah Sakit Umum Daerah Dr. Moewardi. Terdapat dua akses pintu masuk menuju dan keluar rumah sakit yang didasarkan pada SNI 03-1733-2004 tentang jarak ideal pejalan kaki untuk menempuh titik tujuan. Jangkauan penelitian sejauh 400 meter dipilih karena pada jarak tersebut sudah dapat mengidentifikasi perubahan pemanfaatan lahan secara lebih rinci. Berdasarkan radius tersebut, kawasan yang termasuk ke dalam jangkauan penelitian adalah mencakup satu Kelurahan Jebres dengan jumlah 13 RW. Peta kawasan penelitian dapat dilihat dalam Lampiran 2.

\subsection{Metode Analisis}

Penelitian untuk mengidentifikasi "Pengaruh Perubahan Pelayanan Kesehatan Rumah Sakit Umum Daerah Dr. Moewardi Terhadap Pemanfaatan Lahan Komersial di Sekitarnya" ini menggunakan pendekatan deduktif, yaitu penelitian yang dimulai dengan mengkaji teori terkait dengan perubahan pelayanan kesehatan dan pemanfaatan lahan komersial guna mendapatkan arahan dalam 
menentukan kebutuhan data yang akan dijadikan dasar sebagai analisis penelitian.

Variabel yang digunakan dalam penelitian ini adalah perubahan pelayanan kesehatan yang diukur dari jumlah sumber daya manusia, jumlah tempat tidur, dan jumlah pasien sebagai variabel bebas dan pemanfaatan lahan komersial yang diukur dari perubahan luasan lahan dan intensitas lahan sebagai variabel terikat.

Teknik analisis data yang digunakan dalam penelitian ini yaitu:

\subsubsection{Analisis Deskripsi Naratif}

Analisis ini digunakan untuk mengetahui perubahan pelayanan kesehatan Rumah Sakit Umum Daerah Dr. Moewardi dengan pemanfaatan lahan komersial di sekitarnya dengan menggunakan perhitungan kuantitatif untuk mengidentifikasi adanya perubahan serta masukan dari teori terkait disertai dengan penjelasan bersifat deskripsi naratif.

\subsubsection{Analisis Deskripsi Eksplanatif}

Analisis ini digunakan untuk mengetahui perubahan pelayanan kesehatan Rumah Sakit Umum Daerah Dr. Moewardi dengan perubahan pemanfaatan lahan komersial di sekitarnya dengan terlebih dahulu melakukan penilaian pada aspek perubahan pelayanan kesehatan yang dijelaskan dalam Tabel 1 dan penilaian pada aspek pemanfaatan lahan komersial yang dijelaskan dalam Tabel 2 .

Tabel 1. Penilaian Perubahan Pelayanan Kesehatan

\begin{tabular}{|l|l|}
\hline Penilaian & \multicolumn{2}{|l|}{ Keterangan } \\
\hline$-1=$ Perubahan Menurun & $\begin{array}{l}\text { Hal ini menunjukkan } \\
\text { bahwa indikator } \\
\text { pelayanan kesehatan } \\
\text { berubah tapi perubahan } \\
\text { mengalami penurunan } \\
\text { dari tahun sebelumnya }\end{array}$ \\
\hline $\begin{array}{l}\text { Stagnan } \\
\text { Merubahan Tetap/ }\end{array}$ & $\begin{array}{l}\text { Hal ini menunjukkan } \\
\text { bahwa indikator } \\
\text { pelayanan kesehatan } \\
\text { tidak mengalami } \\
\text { perubahan atau stagnan }\end{array}$ \\
\hline $\begin{array}{l}\text { Meningkat } \\
\text { Perubahan }\end{array}$ & $\begin{array}{l}\text { Hal ini menunjukkan } \\
\text { bahwa indikator } \\
\text { pelayanan kesehatan } \\
\text { berubaha dan } \\
\text { perubahan mengalami } \\
\text { peningkatan dari tahun } \\
\text { sebelumnya }\end{array}$ \\
\hline
\end{tabular}

Tabel 2. Penilaian Aspek Pemanfaatan Lahan Komersial

\begin{tabular}{|l|l|}
\hline Penilaian & \multicolumn{2}{|l|}{ Keterangan } \\
\hline$-1=$ Perubahan Menurun & $\begin{array}{l}\text { Hal ini menunjukkan } \\
\text { bahwa pemanfaatan } \\
\text { lahan komersial } \\
\text { berubah tapi perubahan } \\
\text { mengalmi penurunan } \\
\text { dari tahun sebelumnya }\end{array}$ \\
\hline $\begin{array}{l}\text { Hal ini menunjukkan } \\
\text { Stagnan }\end{array}$ & $\begin{array}{l}\text { bahwa pemanfaatan } \\
\text { lahan komersial tidak } \\
\text { mengalami perubahan } \\
\text { atau stagnan }\end{array}$ \\
\hline+1 & $\begin{array}{l}\text { Hal ini menunjukkan } \\
\text { bahwa pemanfaatan } \\
\text { lahan kan komersial } \\
\text { lerubah dan perubahan } \\
\text { mengalami peningkatan } \\
\text { dari tahun sebelumnya }\end{array}$ \\
\hline
\end{tabular}

Setelah dilakukan penilaian pada masingmasing aspek, kemudian peneliti mengidentifikasi pengaruh yang ditimbulkan antar kedua variabel, yakni variabel pengaruh perubahan pelayanan kesehatan Rumah Sakit Umum Daerah Dr. Moewardi dan variabel pemanfaatan lahan komersial di sekitar kawasan rumah sakit. Pengaruh kedua variabel tersebut dijabarkan di Tabel 1 dan Tabel 2 yang ada pada Lampiran 1.

\section{HASIL DAN PEMBAHASAN}

Berdasarkan hasil analisis, diketahui bahwa pelayanan kesehatan yang dilihat dari jumlah sumber daya manusia, jumlah tempat tidur, dan jumlah pasien mengalami perubahan yang meningkat di tahun 2016 serta pemanfaatan lahan komersial di sekitar Rumah Sakit Umum Daerah Dr. Moewardi mengalami perubahan yang meningkat di tahun 2016 juga. Berikut ini merupakan penjabaran dari setiap analisis, yakni:

\subsection{Identifikasi Pengaruh Perubahan Pelayanan Kesehatan Rumah Sakit Umum Daerah Dr. Moewardi Terhadap Perubahan Luasan Lahan di Sekitarnya}

Hasil analisis menjelaskan bahwa semua indikator yang diukur dalam pelayanan kesehatan mengalami perubahan yang meningkat. Hal yang sama juga ditunjukkan dari perubahan luasan lahan yang mengalami perubahan meningkat dengan total jumlah perubahan sebesar $37.275 \mathrm{~m}^{2}$. Perubahan luasan lahan paling tinggi dimiliki oleh lahan dengan kegiatan indekos, yakni sebesar 
$20.584 \mathrm{~m}^{2}$. Perubahan pemanfaataan luasan lahan komersial yang ada di sekitar Rumah Sakit Umum Daerah Dr. Moewardi dijelaskan pada Tabel 3.

Tabel 3. Perubahan Pemanfaatan Luasan Lahan Komersial di Sekitar Rumah Sakit Umum Daerah Dr. Moewardi

\begin{tabular}{|c|c|c|c|}
\hline \multirow{2}{*}{$\begin{array}{l}\text { Jenis } \\
\text { Pemanfaatan } \\
\text { Lahan Komersial }\end{array}$} & \multicolumn{2}{|c|}{ Luasan lahan $\left(\mathrm{m}^{2}\right)$} & \multirow{2}{*}{$\begin{array}{l}\text { Perubahan } \\
\text { Luasan Lahan } \\
\left(\mathrm{m}^{2}\right)\end{array}$} \\
\hline & $\begin{array}{l}\text { Tahun } \\
2007\end{array}$ & $\begin{array}{l}\text { Tahun } \\
2016\end{array}$ & \\
\hline Apotik & 272 & 2.557 & 2.285 \\
\hline Dealer & 14.072 & 16.779 & 2.707 \\
\hline Pertokoan & 5.966 & 10.585 & 4.619 \\
\hline Warung dan Kios & 10.415 & 16.160 & 5.745 \\
\hline Jasa Komersial & 4.517 & 5.852 & 1.335 \\
\hline Indekos & 18.771 & 39.355 & 20.584 \\
\hline \multicolumn{3}{|l|}{ Total Jumlah } & 37.275 \\
\hline
\end{tabular}

(Hasil Survei Lapangan, 2016)

Perubahan tersebut disebabkan oleh meningkatnya jumlah pemangku kepentingan yang terkait dengan rumah sakit, seperti jumlah pasien dengan total jumlah perubahan adalah sebanyak 105.703 orang dari tahun 2007 dan tahun 2016 yang paling banyak berasal dari Kota Surakarta. Total jumlah perubahan sumber daya manusia yang terdiri dari tenaga medis sebanyak 492 orang, tenaga paramedis sebanyak 307 orang, tenaga paramedis non perawatan sebanyak 117 orang, dan tenaga non medis sebanyak 65 orang yang berkaitan dengan rumah sakit karena membutuhkan tempat hunian dan jasa komersial lainnya untuk mendukung kegiatan hariannya yang mengakibatkan luasan pemanfaatan lahan komersil bertambah. Selain itu, pelayanan kesehatan juga dilihat dari jumlah tempat tidur yang diikuti dengan jumlah pengantar keluarga yang menginap di rumah sakit. Jumlah pengantar keluarga ini meningkat sebanyak 178 orang yang berasal dari semua kelas yang ada di Rumah Sakit Umum Daerah Dr. Moewardi.

Dengan meningkatnya pelayanan kesehatan dan pemanfaatan luasan lahan komersial yang ada di sekitar Rumah Sakit Umum Daerah Dr. Moewardi, maka dapat disimpulkan bahwa antara keduanya memiliki pengaruh yang kuat.

Pengaruh tersebut kemudian dibuktikan oleh teori dari Kaiser et al (1995) yang mengemukakan bahwa lahan dengan fungsi kesehatan mempunyai interaksi yang tinggi terhadap fungsi perdagangan dan jasa karena mendukung pemenuhan kebutuhan harian sehingga berimplikasi terhadap perubahan luasan lahan di sekitarnya. Fenomena yang paling dominan adalah terjadinya pemanfaatan lahan komersial berupa indekos yang dipengaruhi oleh meningkatnya jumlah ketenagakerjaan yang sedang melakukan studi akademik di rumah sakit tersebut sehingga membutuhkan tempat tinggal terdekat.

Perubahan pemanfaatan lahan komersial ini kemudian ditunjukkan dengan peta pemanfaatan lahan komersial di sekitar Rumah Sakit Umum Daerah Dr. Moewardi pada tahun 2007 dan 2016 yang dapat dilihat pada Lampiran 3 dan Lampiran 4.

\subsection{Identifikasi Perubahan Pelayanan Kesehatan Rumah Sakit Umum Daerah Dr. Moewardi Terhadap Perubahan Intensitas Lahan Komersial}

Hasil analisis menjelaskan bahwa semua indikator yang diukur dalam pelayanan kesehatan mengalami perubahan yang meningkat dilihat dari seluruh jumlah total perubahan. Hal yang sama juga ditunjukkan dari perubahan intensitas lahan yang diukur dari koefisien dasar bangunan dan koefisien lantai bangunan mengalami perubahan meningkat dengan total jumlah perubahan sebesar $1,49 \%$ untuk koefisien dasar bangunan dan sebesar $0,46 \%$ untuk koefisien lantai bangunan.

Perubahan intensitas lahan komersial yang ada di sekitar Rumah Sakit Umum Daerah Dr. Moewardi dijelaskan pada Tabel 4 dan Tabel 5.

Tabel 4. Perubahan Koefisisen Dasar Bangunan Komersial di Sekitar Rumah Sakit Umum Daerah Dr. Moewardi

\begin{tabular}{|c|c|c|c|}
\hline \multirow{2}{*}{$\begin{array}{l}\text { Jenis } \\
\text { Pemanfaatan } \\
\text { Lahan Komersial }\end{array}$} & \multicolumn{2}{|c|}{$\mathrm{KDB}(\%)$} & \multirow{2}{*}{$\begin{array}{l}\text { Perubahan } \\
\text { KDB } \\
(\%)\end{array}$} \\
\hline & 2007 & 2016 & \\
\hline Apotik & 31,25 & 34,42 & 3,17 \\
\hline Dealer & 28,33 & 31,55 & 3,23 \\
\hline Pertokoan & 36,56 & 31,94 & $-4,62$ \\
\hline Warung dan Kios & 38,82 & 38,21 & $-0,61$ \\
\hline Jasa Komersial & 38,45 & 40,12 & 1,67 \\
\hline Rumah kos & 45,71 & 44,36 & $-1,35$ \\
\hline \multicolumn{3}{|l|}{ Total Jumlah } & 1,49 \\
\hline
\end{tabular}

(Hasil Survei Lapangan, 2016)

Tabel 5. Perubahan Koefisisen Lantai Bangunan Komersial di Sekitar Rumah Sakit Umum Daerah Dr. Moewardi

\begin{tabular}{|l|l|l|l|}
\hline \multirow{2}{*}{$\begin{array}{l}\text { Jenis } \\
\text { Pemanfaatan }\end{array}$} & \multicolumn{2}{|l|}{ KLB $(\%)$} & Perubahan \\
\cline { 2 - 3 } & 2007 & 2016 & KLB \\
\hline
\end{tabular}




\begin{tabular}{|l|l|l|l|}
\hline Lahan Komersial & & & $(\%)$ \\
\hline Apotik & 0,31 & 0,34 & 0,03 \\
\hline Dealer & 0,28 & 0,32 & 0,03 \\
\hline Pertokoan & 0,37 & 0,32 & $-0,05$ \\
\hline Warung dan Kios & 0,39 & 0,38 & $-0,01$ \\
\hline Jasa Komersial & 0,38 & 0,40 & 0,02 \\
\hline Rumah kos & 0,46 & 0,89 & 0,43 \\
\hline Total Jumlah & 0,46 \\
\hline
\end{tabular}

(Hasil Survei Lapangan, 2016)

Perubahan tersebut menunjukkan bahwa terjadi peningkatan koefisien dasar bangunan dan koefisien lantai bangunan di setiap tahunnya. Indekos memiliki lantai bangunan yang lebih banyak dibandingkan dengan kegiatan komersial lainya di tahun 2016. Ini dikarenakan kebutuhan akan indekos yang semakin banyak dibutuhkan oleh pemangku kepentingan tetapi lahan yang tersedia sudah terbatas.

Dengan meningkatnya pelayanan kesehatan dan pemanfaatan intensitas lahan komersial, berupa koefisien dasar bangunan dan koefisien lantai bangunan yang ada di sekitar Rumah Sakit Umum Daerah Dr. Moewardi, maka dapat disimpulkan bahwa antara keduanya memiliki pengaruh yang kuat.

Pengaruh tersebut kemudian dibuktikan oleh Chapin (1985) yang mengemukakan bahwa dengan adanya peningkatan kebutuhan kegiatan manusia yang terjadi di lahan komersial akan menuntut perubahan lahan yang ditandai dengan meningkatnya jumlah lantai bangunan karena keterbatasan lahan untuk mendukung kegiatan tersebut.

\subsection{Analisis Pengaruh Perubahan Pelayanan Kesehatan Rumah Sakit Umum Daerah Dr. Moewardi Terhadap Perubahan Pemanfaatan Lahan Komersial di Sekitarnya}

Pemanfaatan lahan komersial yang ada di sekitar kawasan Rumah Sakit Umum Daerah Dr. Moewardi mengalami perubahan yang meningkat dan pemanfaatan lahan komersial pun mengalami perubahan yang meningkat juga. Perubahan tersebut ditandai dengan meningkatnya total jumlah perubahan di masing-masing sub variabel yang telah diteliti. Dengan meningkatnya perubahan pelayanan kesehatan yang terdiri dari jumlah sumber daya manusia (tenaga medis, tenaga paramedis, tenaga paramedis non perawatan, dan tenaga non medis), jumlah tempat tidur yang diikuti dengan jumlah pengantar keluarga, serta jumlah pasien dan perubahan pemanfaatan lahan komersial yang terdiri dari luasan lahan serta intensitas lahan dari tahun 2007 dan tahun 2016 menandakan bahwa adanya pengaruh yang kuat diantaranya keduanya.

Pengaruh kuat tersebut kemudian dibuktikan dengan teori umum dari penelitian ini, yakni dari Lynch dalam (Marhendriyanto, 2003) yang mengemukakan bahwa keberadaan pusat kegiatan utama seperti rumah sakit pada suatu kawasan akan mengakibatkan muncul dan berkembangnya kegiatan-kegiatan pendukung di sekitar kawasan. Dengan didukung teori tersebut, maka membuktikan bahwa adanya keterkaitan antara keberadaan rumah sakit yang ditandai dari kegiatan pelayanan kesehatan Rumah Sakit Umum Daerah Dr. Moewardi yang kemudian mempengaruhi perubahan lahan, khususnya lahan komersial di sekitar rumah sakit.

\section{KESIMPULAN}

Keberadaan pelayanan kesehatan yang dilakukan oleh Rumah Sakit Umum Daerah Dr. Moewardi memberikan pengaruh terhadap pemanfaatan lahan untuk kegiatan komersial di sekitar kawasan rumah sakit. Berdasarkan hasil analisis yang telah dilakukan terlihat bahwa terjadinya peningkatan pemanfaatan lahan untuk kegiatan komersial seperti indekos, warung makan, pertokoan (toko yang menjual kebutuhan harian, toko alat kesehatan, toko alat tulis, dan lain sebagainya), jasa komerisal (jasa laundry, jasa fotokopi, jasa pengkreditan, jasa komunikasi, dan bengkel), dealer, serta apotik di sekitar Rumah Sakit Umum Daerah Dr. Moewardi di tahun 2016 dengan total perubahan sebesar $37.275 \mathrm{~m}^{2}$. Kegiatan komersial tersebut tersebar di sepanjang jalan utama rumah sakit, seperti pertokoan, apotik, dan dealer dan juga berada di tengah-tengah permukiman, seperti indekos dan warung makan. Hal ini dikarenakan kegiatan komersial tersebut dekat dengan Rumah Sakit Umum Daerah Dr. Moewardi sehingga lebih mudah dijangkau oleh pemangku kepentingan yang ada di rumah sakit tersebut.

Kegiatan indekos muncul dikarenakan adanya tuntutan untuk memenuhi kebutuhan 
hunian bagi pemangku kepentingan Rumah Sakit Umum Daerah Dr. Moewardi seperti dokter yang sedang dalam masa akademik atau biasa dikenal dengan dokter PPDS/ residen. Dokter tersebut kebanyakan memilih bertempat tinggal dekat dengan rumah sakit agar dapat lebih mudah melakukan mobilisasi ke rumah sakit, tenaga perawat yang bekerja baik dalam masa pendidikan maupun sebagai pegawai, dan juga pasien yang sedang menjalani masa pengobatan tetapi tidak tinggal di rumah sakit. Dari cakupan pelayanan yang ada, asal kunjungan pasien paling banyak berasal dari Kota Surakarta dan diikuti dengan Kabupaten Karanganyar, Kabupaten Sukoharjo, serta sebagian wilayah Jawa Timur yang merupakan penghuni indekos di sekitar kawasan Rumah Sakit Umum Daerah Dr. Moewardi. Hal yang sama juga terjadi untuk lahan dengan kegiatan komersial lainnya, seperti warung makan, jasa komersial, dealer, apotik, pertokoan yang muncul dikarenakan mendukung kegiatan harian yang dilakukan pemangku kepentingan Rumah Sakit Umum Daerah Dr. Moewardi tinggal di rumah sakit.

\section{REFERENSI}

Chapin, F. Stuart. 1985. Urban Land Use Planning. Chicago: University Of Illinois Press.

Kaiser, et al. 1995. Urban Land Use Planning. Chicago: University Of Illinois Press.

Marhendriyanto, Beta. 2003. Pengaruh Kampus Perguruan Tinggi Terhadap Perubahan Kawasan Sekitarnya di Kota Semarang. Universitas Diponegoro. Semarang.

Peta RBI Indonesia

SNI 03-1733-2004 Tentang Jarak Ideal Pejalan Kaki

Tarigan, S. 2005. Perencanaan Pembangunan Wilayah: Jakarta. Bumi Aksara.

Wicaksono, Tangguh. 2011. Analisis FaktorFaktor Yang Mempengaruhi Perubahan Pemanfaatan Perumahan Untuk Tujuan Komersial Di Kawasan Tlogonsari Kulon, Semarang. Universitas Diponegoro, Semarang. 


\section{LAMPIRAN}

\section{Lampiran 1}

Tabel 1 Pengaruh Perubahan Pelayanan Kesehatan Rumah Sakit Terhadap Pemanfaatan Lahan Komersial

\begin{tabular}{|c|c|c|c|}
\hline $\begin{array}{l}\text { PerubahanPelayanan } \\
\text { kesehatan } \\
\text { Rumah Sakit }\end{array}$ & Perubahan Menurun & $\begin{array}{c}\text { Perubahan Tetap/ } \\
\text { Stagnan }\end{array}$ & Perubahan Meningkat \\
\hline Perubahan Menurun & $\begin{array}{c}\text { Pengaruh A } \\
\text { (Kuat) }\end{array}$ & $\begin{array}{l}\text { Pengaruh B } \\
\text { (Sedang) }\end{array}$ & $\begin{array}{c}\text { Pengaruh C } \\
\text { (Lemah) }\end{array}$ \\
\hline Perubahan Tetap/ Stagnan & $\begin{array}{l}\text { Pengaruh D } \\
\text { (Sedang) }\end{array}$ & $\begin{array}{c}\text { Pengaruh E } \\
\text { (Kuat) }\end{array}$ & $\begin{array}{l}\text { Pengaruh F } \\
\text { (Sedang) }\end{array}$ \\
\hline Perubahan Meningkat & $\begin{array}{l}\text { Pengaruh G } \\
\text { (Lemah) }\end{array}$ & $\begin{array}{l}\text { Pengaruh H } \\
\text { (Sedang) }\end{array}$ & $\begin{array}{l}\text { Pengaruh I } \\
\text { (Kuat) }\end{array}$ \\
\hline
\end{tabular}

Tabel 2 Penjelasan Pengaruh Perubahan Pelayanan Kesehatan Rumah Sakit Terhadap Pemanfaatan Lahan Komersial

\begin{tabular}{|c|c|c|c|}
\hline No. & Tipe Pengaruh & Penjelasan & Keterangan \\
\hline 1 & $\begin{array}{l}\text { Pengaruh A } \\
\text { (Kuat) }\end{array}$ & $\begin{array}{l}\text { Pelayanan Kesehatan Rumah Sakit Umum } \\
\text { Daerah Dr. Moewardi dan pemanfaatan } \\
\text { lahan komersial di sekitarnya sama-sama } \\
\text { mengalami perubahan menurun }\end{array}$ & $\begin{array}{l}\text { Hal ini menunjukkan bahwa perubahan } \\
\text { pelayanan kesehatan Rumah Sakit Umum } \\
\text { Daerah Dr. Moewardi mempengaruhi } \\
\text { pemanfaatan lahan komersial di sekitar } \\
\text { kawasan karena total jumlah perubahan } \\
\text { keduanya mengalami penurunan dari tahun } \\
\text { 2007 hingga tahun } 2016\end{array}$ \\
\hline 2 & $\begin{array}{l}\text { Pengaruh B } \\
\text { (Sedang) }\end{array}$ & $\begin{array}{l}\text { Pelayanan kesehatan Rumah Sakit Umum } \\
\text { Daerah Dr. Moewardi mengalami } \\
\text { perubahan menurun akan tetapi } \\
\text { pemanfataan lahan komersial di } \\
\text { sekitarnya tidak mengalami perubahan/ } \\
\text { stagnan }\end{array}$ & $\begin{array}{l}\text { Hal ini menunjukkan bahwa perubahan } \\
\text { pelayanan kesehatan Rumah Sakit Umum } \\
\text { Daerah Dr. Moewardi tidak mempengaruhi } \\
\text { pemanfaatan lahan komersial di sekitar } \\
\text { kawasan karena pelayanan kesehatan } \\
\text { memiliki total jumlah perubahan yang } \\
\text { menurun tetapi pemanfaatan lahan komersial } \\
\text { memiliki total jumlah perubahan yang } \\
\text { stagnan dari tahun } 2007 \text { hingga tahun } 2016 \text {. }\end{array}$ \\
\hline 3 & $\begin{array}{l}\text { Pengaruh C } \\
\text { (Lemah) }\end{array}$ & $\begin{array}{l}\text { Pelayanan kesehatan Rumah Sakit Umum } \\
\text { Daerah Dr. Moewardi mengalami } \\
\text { perubahan menurun akan tetapi } \\
\text { pemanfaatan lahan komersil mengalami } \\
\text { perubahan meningkat }\end{array}$ & $\begin{array}{l}\text { Hal ini menunjukkan bahwa perubahan } \\
\text { pelayanan kesehatan Rumah Sakit Umum } \\
\text { Daerah Dr. Moewardi dengan total jumlah } \\
\text { perubahan yang menurun tidak berpengaruh } \\
\text { terhadap kondisi pemanfaatan lahan } \\
\text { komersial di sekitar kawasan yang } \\
\text { mengalami perubahan peningkatan dari } \\
\text { tahun } 2007 \text { hingga tahun } 2016 \text {. }\end{array}$ \\
\hline 4 & $\begin{array}{l}\text { Pengaruh D } \\
\text { (Sedang) }\end{array}$ & $\begin{array}{l}\text { Pelayanan kesehatan Rumah Sakit Umum } \\
\text { Daerah Dr. Moewardi tidak mengalami } \\
\text { perubahan/ stagnan akan tetapi } \\
\text { pemanfaatan lahan komersil mengalami } \\
\text { perubahan menurun }\end{array}$ & $\begin{array}{l}\text { Hal ini menunjukkan bahwa pelayanan } \\
\text { kesehatan Rumah Sakit Umum Daerah Dr. } \\
\text { Moewardi dengan total jumlah perubahan } \\
\text { yang stagnan tidak berpengaruh terhadap } \\
\text { total jumlah perubahan pemanfaatan lahan } \\
\text { komersial di sekitar kawasan yang } \\
\text { mengalami penurunan dari tahun } 2007 \\
\text { hingga tahun } 2016 \text {. }\end{array}$ \\
\hline 5 & $\begin{array}{c}\text { Pengaruh E } \\
\text { (Kuat) }\end{array}$ & $\begin{array}{l}\text { Pelayanan kesehatan Rumah Sakit Umum } \\
\text { Daerah Dr. Moewardi dan pemanfaatan } \\
\text { lahan komersil sama-sama tidak } \\
\text { mengalami perubahan }\end{array}$ & $\begin{array}{l}\text { Hal ini menunjukkan bahwa pelayanan } \\
\text { kesehatan Rumah Sakit Umum Daerah Dr. } \\
\text { Moewardi mempengaruhi pemanfaatan } \\
\text { lahan komersial di sekitar kawasan karena } \\
\text { total jumlah perubahan keduanya sama-sama } \\
\text { tidak mengalami perubahan atau stagnan } \\
\text { dari tahun } 2007 \text { hingga tahun } 2016 \text {. }\end{array}$ \\
\hline
\end{tabular}




\begin{tabular}{|c|c|c|c|}
\hline No. & Tipe Pengaruh & Penjelasan & Keterangan \\
\hline 6 & $\begin{array}{l}\text { Pengaruh F } \\
\text { (Sedang) }\end{array}$ & $\begin{array}{l}\text { Pelayanan kesehatan Rumah Sakit Umum } \\
\text { Daerah Dr. Moewardi tidak mengalami } \\
\text { perubahan/ stagnan akan tetapi } \\
\text { pemanfaatan lahan komersil mengalami } \\
\text { perubahan meningkat }\end{array}$ & $\begin{array}{l}\text { Hal ini menunjukkan bahwa pelayanan } \\
\text { kesehatan Rumah Sakit Umum Daerah Dr. } \\
\text { Moewardi dengan total jumlah perubahan } \\
\text { perubahan yang stagnan tidak berpengaruh } \\
\text { terhadap total jumlah perubahan } \\
\text { pemanfaatan lahan komersial di sekitar } \\
\text { kawasan yang mengalami perubahan } \\
\text { peningkatan dari tahun } 2007 \text { hingga tahun } \\
2016 \text {. }\end{array}$ \\
\hline 7 & $\begin{array}{c}\text { Pengaruh G } \\
\text { (Lemah) }\end{array}$ & $\begin{array}{l}\text { Pelayanan kesehatan Rumah Sakit Umum } \\
\text { Daerah Dr. Moewardi mengalami } \\
\text { perubahan yang meningkat akan tetapi } \\
\text { pemanfaatan lahan komersil mengalami } \\
\text { perubahan menurun }\end{array}$ & $\begin{array}{l}\text { Hal ini menunjukkan bahwa pelayanan } \\
\text { kesehatan Rumah Sakit Umum Daerah Dr. } \\
\text { Moewardi dengan total jumlah perubahan } \\
\text { yang meningkat tidak berpengaruh terhadap } \\
\text { total jumlah perubahan pemanfaatan lahan } \\
\text { komersial di sekitar kawasan yang } \\
\text { mengalami penurunan dari tahun } 2007 \\
\text { hingga tahun 2016. }\end{array}$ \\
\hline 8 & $\begin{array}{l}\text { Pengaruh H } \\
\text { (Sedang) }\end{array}$ & $\begin{array}{l}\text { Pelayanan kesehatan Rumah Sakit Umum } \\
\text { Daerah Dr. Moewardi mengalami } \\
\text { perubahan yang meningkat akan tetapi } \\
\text { pemanfaatan lahan komersil tidak } \\
\text { mengalami perubahan/ stagnan }\end{array}$ & $\begin{array}{l}\text { Hal ini menunjukkan bahwa pelayanan } \\
\text { kesehatan Rumah Sakit Umum Daerah Dr. } \\
\text { Moewardi dengan total jumlah perubahan } \\
\text { yang meningkat tidak berpengaruh terhadap } \\
\text { total jumlah perubahan pemanfaatan lahan } \\
\text { komersial di sekitar kawasan yang } \\
\text { mengalami perubahan stagnan dari tahun } \\
2007 \text { hingga tahun } 2016 \text {. }\end{array}$ \\
\hline 9 & $\begin{array}{l}\text { Pengaruh I } \\
\text { (Kuat) }\end{array}$ & $\begin{array}{l}\text { Pelayanan kesehatan Rumah Sakit Umum } \\
\text { Daerah Dr. Moewardi dan pemanfaatan } \\
\text { lahan komersil sama-sama mengalami } \\
\text { perubahan meningkat }\end{array}$ & $\begin{array}{l}\text { Hal ini menunjukkan bahwa pelayanan } \\
\text { kesehatan Rumah Sakit Umum Daerah Dr. } \\
\text { Moewardi mempengaruhi pemanfaatan } \\
\text { lahan komersial di sekitar kawasan karena } \\
\text { total jumlah perubahan keduanya mengalami } \\
\text { perubahan yang meningkat dari tahun } 2007 \\
\text { hingga tahun 2016. }\end{array}$ \\
\hline
\end{tabular}

\section{Lampiran 2}

\section{Lampiran 3}

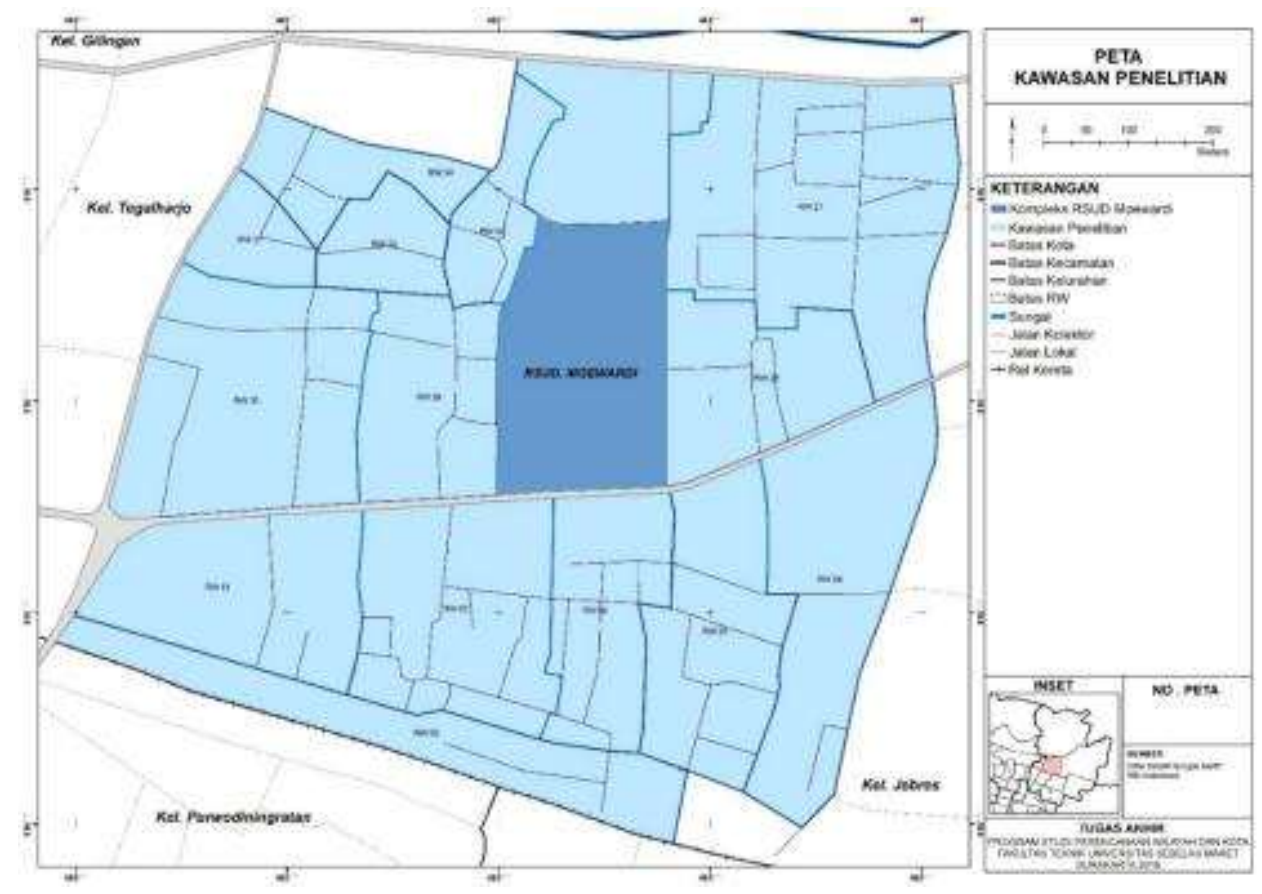

Peta Kawasan Penelitian

(Citra Satelit 2016 dan Peta RBI Indonesia) 


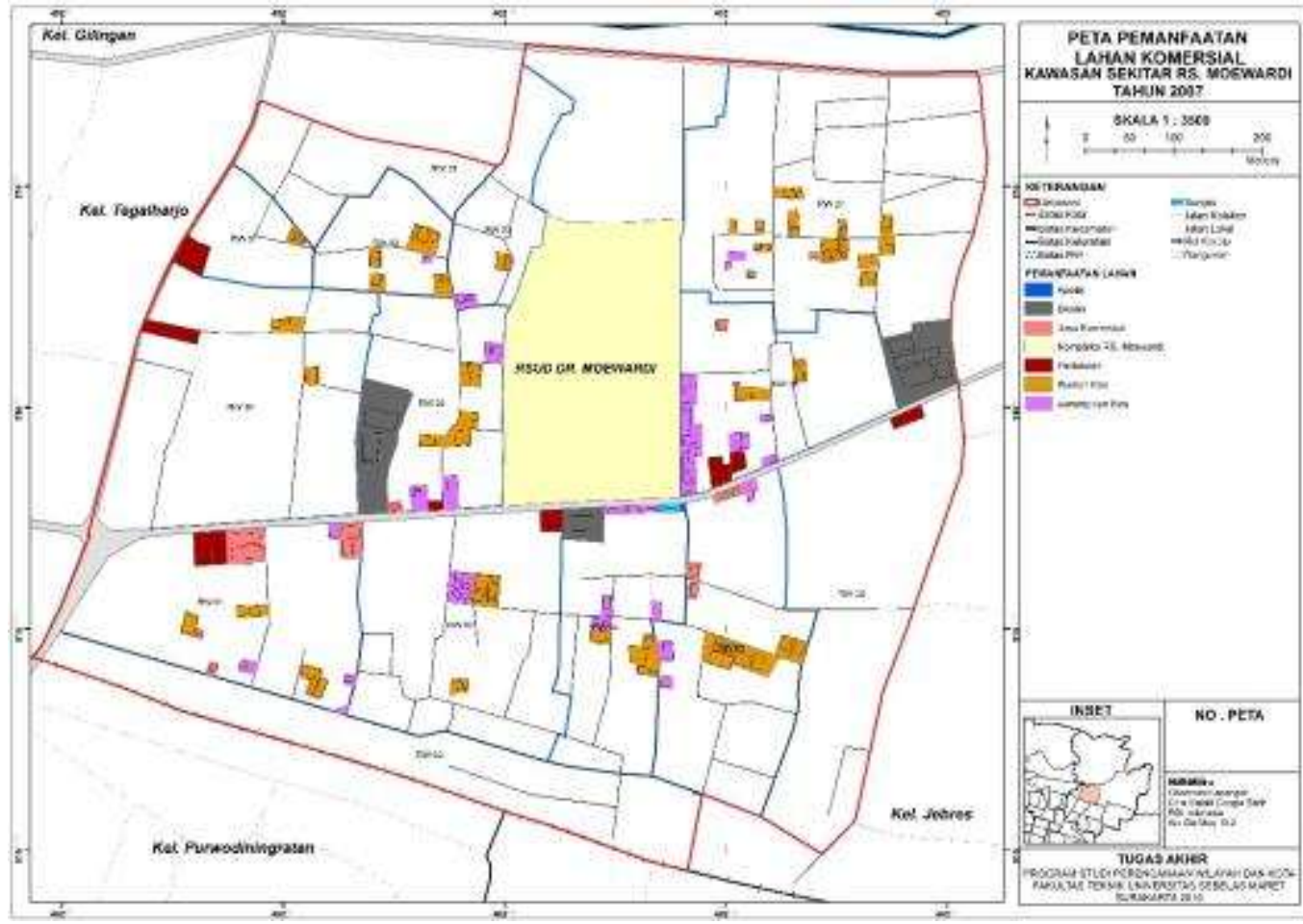

Peta Pemanfaatan Lahan Komersial Tahun 2007 (Hasil Survei Lapangan, 2016)

Lampiran 4

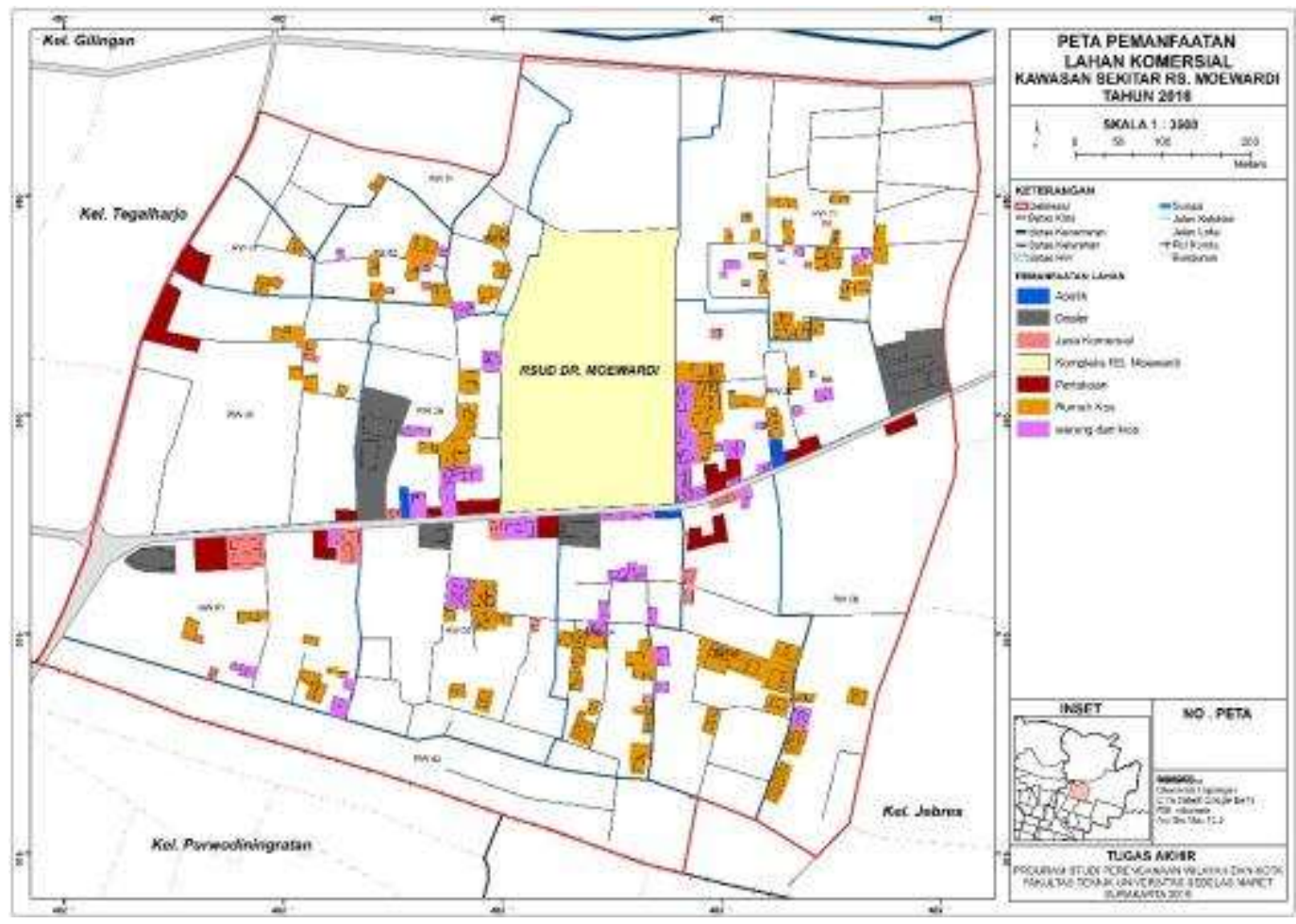

Peta Pemanfaatan Lahan Komersial Tahun 2016

(Hasil Survei Lapangan, 2016) 